\title{
Avoidance of milk and dairy products after oral surgery-is such a recommendation still valid? A cross-sectional study among German and international oral and maxillofacial surgeons and dental practitioners with review of the literature
}

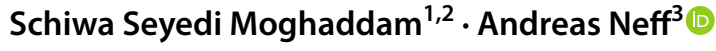

Received: 14 July 2021 / Accepted: 17 October 2021 / Published online: 25 October 2021

(c) The Author(s) 2021

\begin{abstract}
Purpose For prevention of wound-healing complications, patients in German-speaking countries are traditionally advised to avoid consumption of milk and dairy products after oral surgery. In the absence of national and international guidelines, this study investigates scientific evidence and compares international practice, frequency scale, and rationale behind such recommendation.

Methods Comparison of a German cross-sectional mono-center-questionnaire pilot study and a survey among international oral and maxillofacial surgeons (OMFS), specialized oral surgeons and general dentists, evaluating international practice regarding post-operative dietary and nutrition recommendations. Our literature review further assessed scientific evidence for relevant effects of probiotics, prebiotics, and/or synbiotics.

Results Among German study participants, 56\% $(n=64 / 114)$ advise patients to avoid milk and dairy products, with $42 \%$ of OMFS $(n=38)$ and $65 \%(n=76)$ of the general dentists recommending abstention $(p=.027)$. In striking contrast, such recommendation could not be identified in our international survey $(n=143)(t$ test, $p<.001)$ nor in the literature. There were significant differences between German and international study participants regarding the rationale for dietary recommendations, with dental schools and literature most frequently indicated as sources (Fisher's exact test, $p<.001$ ).

Conclusion The hypothesis of a harmful effect of the consumption of milk and dairy products after dentoalveolar surgery could not be supported by evidence. The recommendation to avoid dairy products post-surgery was identified as a specific phenomenon practiced almost exclusively in German-speaking countries. Corresponding recommendations, most probably based on a now irrelevant risk of contracting tuberculosis from milk products, can at present no longer be substantiated.
\end{abstract}

Keywords Milk · Dairy products · Oral surgery $\cdot$ Wound healing

Schiwa Seyedi Moghaddam

schiwa.seyedi@gmail.com

Andreas Neff

neffa@med.uni-marburg.de

1 Dental Office Dr. Jalali Sohi, 63796 Kahl am Main, Germany

2 Philipps University of Marburg, Biegenstraße 10, 35037 Marburg, Germany

3 Klinik and Poliklinik für Mund-, Kieferand Gesichtschirurgie (Oral and Maxillofacial Surgery), Universitätsklinikum Marburg, 35033 Marburg, Germany

\section{Introduction}

Nearly 3.5 billion people worldwide are affected by oral diseases [1]. According to statistics, dolor post extractionem occurs in 3 to $4 \%$ of all tooth extractions [2]. In order to avoid serious complications, patients are routinely advised to abstain from nicotine, alcohol, and caffeine after dental surgery, among others.

In addition, patients in German speaking countries are traditionally advised to avoid milk and dairy products after dentoalveolar surgery. This recommendation can be found in postoperative recommendations for patients as issued by health insurance companies, on numerous internet pages of the German lay press and in internet 
forums [3]. A Google search for the German search terms "dairy products" and "tooth" ("Milchprodukte" \& "Zahn") returned 354,000 entries; a search for the German for "milk" and "implant" ("Milch" \& "Implantat") as many as 820,000 entries, the great majority of which on the subject of abstention from milk and dairy products after oral surgery $[4,5]$. However, no guidelines or evidence for a possible causal link with intraoral infections of wounds exist for the consumption of milk and dairy products following dentoalveolar surgery, neither in Germany, e.g., from the Association of Scientific Medical Societies in Germany (Wissenschaftliche Medizinische Fachgesellschaften, AWMF) nor worldwide, e.g., from the American Dental Association (ADA) or the National Institute for Health and Care Excellence (NICE). We investigated the recommendations as made by dentists and OMFS in Germany by way of a pilot study based on a representative collective of general dentists in private practice and specialized OMFS, with the result that not only more than half of German general therapists; also, over $40 \%$ of specialists for oral surgery and OMFS advised to abstain from consumption of milk and dairy products after dentoalveolar surgical procedures [6]. The study also revealed a major inhomogeneity of the reasons given for such a recommendation [6] (see Table 1).

We were wondering how relevant recommendations are in the rest of the world compared to the above. The study in hand aims for clarification of the following questions: (a) How do recommendations of German dentists and OMFS differ from recommendations worldwide? (b) Which pathophysiological reason supports the recommendation to abstain from dairy products? (c) Does a review find evidence for such a recommendation?

\section{Material and methods}

\section{Literature review}

Electronic and manual literature searches were conducted, and studies published until January 2021 were considered. A PubMed search to retrieve the pertinent literature published in English was made, using the following search strings: "milk products" AND "oral surgery", "dairy products" AND "oral surgery", "dairy" AND "wound healing", "dairy" AND "wound infection", "milk" AND "wound infection", "probiotics" AND "wound infection", "dry socket" AND "dairy", "dry socket" AND "milk", "probiotics" AND "wound healing." Study selection, validation of eligibility, and quality assessment were performed by two independent reviewers. Disagreement was resolved on the basis of discussion.

In addition to a search for pertinent literature in German through EMBASE, a manual search of the historic collection of the library at the Philipps-Universität Marburg and the German National Library (Deutsche Nationalbibliothek) was conducted.

For our probiotics review we included in vitro studies, animal studies and clinical studies in which wound healing and wound infection under therapy with probiotics was examined. We included all RCT studies on all types of probiotic, prebiotic, or synbiotic treatments in humans, aimed to examine postoperative complications after surgery.

Table 1 Arguments in favor of abstention from milk and dairy products after dentoalveolar surgery and their frequency, compared between German and international sample

\begin{tabular}{|c|c|c|}
\hline Arguments in favor of abstention from milk and dairy products after dental procedure & $\begin{array}{l}\text { Frequency } \\
\text { Germany }\end{array}$ & $\begin{array}{l}\text { Frequency } \\
\text { International }\end{array}$ \\
\hline a. Milk and dairy products increase risk of infection & $\begin{array}{l}38.6 \% \\
* * a, b\end{array}$ & $\begin{array}{l}19.8 \% \\
* * * a, b\end{array}$ \\
\hline b. Lactic acid bacteria may adversely affect wound healing & $\begin{array}{l}30.7 \% \\
* * a, * b\end{array}$ & $\begin{array}{l}15.8 \% \\
* * * a, b, * * \mathrm{c}\end{array}$ \\
\hline c. Possible adverse effect on development of coagulum, coagulum surface may disintegrate & $\begin{array}{l}23.7 \% \\
* \mathrm{a}\end{array}$ & $\begin{array}{l}12.2 \% \\
* * * a, * * b\end{array}$ \\
\hline d. Possible reduced efficiency of antibiotics & $\begin{array}{l}5.3 \% \\
* * b\end{array}$ & $2.7 \%$ \\
\hline e. Dairy products my cause tuberculosis infection (specifically unpasteurized raw milk products) & $1.8 \%$ & $0.9 \%$ \\
\hline f. milk may react with resorbable suture (adhesion, mucous congestion) & $1.8 \%$ & $\begin{array}{l}0.9 \% \\
* \mathrm{c}\end{array}$ \\
\hline
\end{tabular}

*Correlation is significant at $p<0.05$ level (Fisher's exact test)

**Correlation is significant at $p<0.01$ level (Fisher's exact test)

$* * *$ Correlation is significant at $p<0.001$ level (Fisher's exact test)

${ }^{\mathrm{a}}$ Correlation oral surgeons/OMFS ${ }^{\mathrm{b}}$ Correlation dentists/OMFS ${ }^{\mathrm{c}}$ Correlation dentists/oral surgeons 
Due to the small number of relevant studies, all available studies covering the effects of milk and dairy products (with the exception of probiotics) on wounds and saliva composition up to and including January 2021 were included. We excluded studies that did not inform about sample sizes and the mean results. Also, we excluded duplicate studies and experiments that include repeated data.

\section{German pilot study and international survey}

Concerning recommendations by German dentists on consumption of dairy products after dentoalveolar surgery, the data had been compiled during our preceding pilot study, with a total of 114 participating dentists and OMFS which has been already published in German before [6]

To investigate relevant recommendations in other countries, in Europe, the members of the European Society of TMJ Surgeons (ESTMJS) and the Italian Academy of Osseointegration (IAO) were contacted in writing; so, there were an additional 143 active surgeons worldwide from the areas of OMFS, dentoalveolar surgery, and periodontology, with a request for information both on the general received scientific consensus in the relevant country on recommendations on the consumption of milk and dairy products following dentoalveolar surgery and on own individual practice.

The power of the questionnaire was calculated using PASS 14.0.9 statistics software. It could be established that from a minimum number of 88 eligible data sets and an equivalence distance of 0.05 the power was 0.95 . Significant differences between the groups "disapprove of abstinence" and "support recommendation for abstinence from milk and dairy products after oral surgery" were therefore detected $(t$ test). Significance level was $p<0.05$.

\section{Results}

\section{Literature review}

A total of 380 abstracts were identified through electronic search, after removal of duplicates. Of these, 49 articles were assessed for full-text evaluation, resulting in a final selection of 36 articles for qualitative assessment. The Germanlanguage literature search in the historic collection of the Philipps-Universität Marburg produced two volumes which matched our inclusion criteria.

Probiotics were shown to promote wound healing in in vitro studies and various human and animal models by increasing collagen concentration, granulation tissue, and angiogenesis [7-37]. Please refer to Tables 2, 3, and 4 for treatment indications and used probiotics. In one study, the mean outcome demonstrated no significant difference in wound healing after third molar extraction between the probiotic group and the control group [39].

\section{German pilot study and international survey}

For our German pilot study [6], a total of 150 dentists $(n=103)$, specialist dentists for oral surgery $(n=30)$, and OMFS $(n=17)$ were contacted in writing. The overall response rate for all questionnaires in the German pilot study was $76 \%$ ( $n=114$, of which 76 dentists, 25 specialist dentists for oral surgery and 13 OMFS). For our international survey, we contacted 143 active specialist surgeons in the areas of OMFS $(n=61)$, dentoalveolar surgery $(n=6)$, and periodontology $(n=76)$ in writing. Here, the overall response rate was $75.5 \%(n=108,45$ of which OMFS, 6 specialist dentists for oral surgery and 57 periodontists) (Table 5). For the nationalities of the participants in the international survey by questionnaire and its result, please refer to Table 6 . Our international survey revealed that only in the Germanspeaking areas and Flanders dentists continue to recommend abstention from consumption of dairy products after dentoalveolar surgery (Table 6). Globally, a total of $95.3 \%$ of study participants stated they did not make any recommendation to abstain from consumption of milk and dairy products after dentoalveolar surgery. Those $4.7 \%$ surveyed who advised so were all from German-speaking and Flemish-speaking geographies (Germany, Austria, Switzerland, and Belgium). Actually, in Italy, India, Thailand, and the USA, some surgeons explicitly recommend the consumption of dairy products, e.g., milk shakes, ice cream, or yoghurt.

In contrary, in Germany, the result was almost diametrically opposed to the international survey. Here, $56.1 \%$ of the sample stated that they advised against consumption of dairy products after surgical procedures in the oral cavity-especially when patients inquire accordingly (see Table 7). While statistically there is no unequivocal consensus or even a clearly prevalent opinion among the German survey, a comparison between the international survey and the German survey nevertheless shows a highly significant difference.

While in the international survey, recommendations are highly uniform and independent from the specialization of the OMFS, oral surgeon, or periodontist (i.e., no recommendation to abstain from dairy products), in Germany, the relevant recommendation was shown to be contingent on if there had been a completion of advanced surgical training. On inquiry by the patient, $64.9 \%$ of German general dentists recommended to abstain from dairy products, while a mere $42.1 \%$ of German OMFS and specialized dentists for oral surgery do so (Table 7), evidencing a significant difference between these two groups in the German collective $(p=0.027)$. At the same time, however, there was no 
Table 2 Characteristics of 17 animal model studies of the effect of probiotics on wound healing

\begin{tabular}{|c|c|c|c|}
\hline First author, year & Study type & Probiotic & Findings (effect of probiotics on wound) \\
\hline Valdez, 2005 [7] & $\begin{array}{l}\text { Animal model study } \\
\text { and in vitro study }\end{array}$ & L. plantarum & Enhanced wound healing \\
\hline Brachkova, 2011 [9] & Animal model study & L. plantarum & $\begin{array}{l}\text { Reduction of Pseudomonas aeruginosa in } \\
\text { wound }\end{array}$ \\
\hline Nasrabadi, 2011 [10] & Animal model study & L. brevis and L. plantarum & $\begin{array}{l}\text { Decreased inflammation and improved wound } \\
\text { healing }\end{array}$ \\
\hline Jones, 2012 [11] & Animal model study & L. fermentum & Enhanced wound healing \\
\hline Poutahidis, 2013 [12] & Animal model study & L. reuteri & Enhanced wound healing \\
\hline Partlow, 2016 [14] & Animal model study & S. bouladrii & $\begin{array}{l}\text { Unimproved wound healing, unchanged micro- } \\
\text { biome }\end{array}$ \\
\hline Argenta, 2016 [15] & Animal model study & L. plantarum & $\begin{array}{l}\text { Decreased mortality and production of inflam- } \\
\text { matory markers (TNF- } \alpha \text {, IL } 6 \text { and 10), less } \\
\text { septicemic accumulation in organs }\end{array}$ \\
\hline Satish, 2017 [16] & Animal model study & L. plantarum & $\begin{array}{l}\text { Reduced severity and length of infection and } \\
\text { collagen concentration (less scarring) }\end{array}$ \\
\hline Oryan, 2018 [17] & Animal model study & S. cerevisiae & Enhanced burn wound healing \\
\hline Ong, 2019 [18] & Animal model study & L. plantarum & $\begin{array}{l}\text { Enhanced wound healing, suppressed Staphylo- } \\
\text { coccus aureus infection at wound }\end{array}$ \\
\hline Tagliari, 2019 [19] & Animal model study & $\begin{array}{l}\text { L. paracasei, B. lactis, L. rhamnosus, } L \text {. } \\
\text { acidophilus }\end{array}$ & $\begin{array}{l}\text { Enhanced wound healing, increased collagen } \\
\text { production }\end{array}$ \\
\hline Khodaii, 2019 [20] & Animal model study & L. reuteri & $\begin{array}{l}\text { Enhanced collagen production, accelerated } \\
\text { wound healing }\end{array}$ \\
\hline Han, 2019 [21] & Animal model study & L. reuteri & $\begin{array}{l}\text { Promoted wound healing through activation of } \\
\text { GMSCs }\end{array}$ \\
\hline Han, $2020[26]$ & Animal model study & L. reuteri & $\begin{array}{l}\text { Inhibited inflammation and enhanced wound } \\
\text { healing through promoting MSCs }\end{array}$ \\
\hline Mohtashami, 2020 [23] & Animal model study & L. bulgaricus, L. plantarum & Enhanced wound healing \\
\hline Ong, 2020 [24] & Animal model study & L. plantarum & $\begin{array}{l}\text { Suppressed Staphylococcus aureus, and thereby } \\
\text { improved wound healing }\end{array}$ \\
\hline Moreira, 2021 [25] & Animal model study & L. johnsonii, L. paracasei, and L. rhamnosus & $\begin{array}{l}\text { Promoted skin wound closure and decreased } \\
\text { scar formation and inflammation }\end{array}$ \\
\hline
\end{tabular}

L., Lactobacillus; S., Saccharomyces; B, Bifidobacterium; GMSC, gingival mesenchymal stem cells; MSC, mesenchymal stem cell

significant difference in recommendations made between German OMFS and specialized dentists for oral surgery (Table 7). Table 8 shows possible sources of information which may motivate a recommendation to abstain from dairy products after surgical procedures in the oral cavity. Table 1 lists the reasons stated by participants in the German pilot study [6] and the international survey and possible arguments in favor of abstention from milk and dairy products after dentoalveolar surgery.

\section{Discussion}

Contrary to the received opinion well established among German dentists and OMFS [6], no evidence can be found in the pertinent literature supporting adverse effects of consumption of milk and dairy products after dentoalveolar surgery.
According to the findings of our survey, in the majority of countries, avoidance of dairy products is not recommended after dentoalveolar surgery (see Table 6), while the majority of the international surveys adopt a neutral position. In countries such as Italy, India, Thailand, and the USA, surgeons actually make recommendation in favor of consumption of dairy products like milkshakes, ice cream, or yoghurt after dentoalveolar surgery, due to their satiating and cooling effects on the surgical site. A common practice is asking the patient to start having ice cream around $30 \mathrm{~min}$ to $1 \mathrm{~h}$ post any minor surgical procedure.

Diametrically opposed the situation in the Germanspeaking and related regions (e.g., Flanders in Belgium): in our German survey, a slight majority (56.1\%) was reported to advise their patients against consumption of milk and dairy products [6], with a significant difference between dentists and OMFS in Germany ( $p=0.027$ ) (see Table 7), of which those with a focus on surgical procedures attributed at least a minor positive effect on wound 
Table 3 Characteristics of 13 studies in humans with probiotics on wound healing

\begin{tabular}{|c|c|c|c|c|}
\hline First author, year & Study type & $\begin{array}{l}\text { Patients: pro- } \\
\text { biotic/control } \\
\text { group }\end{array}$ & Probiotic & $\begin{array}{l}\text { Findings: } \\
\text { Effect of probiotics on wound }\end{array}$ \\
\hline Rayes, 2002 [27] & Prospective & $30 / 30$ & L. plantarum & Incidence of infections significantly lower \\
\hline Kanazawa, 2005 [28] & $\mathrm{RCT}$ & $21 / 23$ & L. casei, B. breve & $\begin{array}{l}\text { Decreased quantity of pathogens in sym- } \\
\text { biotic group, thereby less surgical-site } \\
\text { infections }\end{array}$ \\
\hline Sugawara, 2006 [29] & $\mathrm{RCT}$ & $40 / 41$ & L. casei, B. breve & $\begin{array}{l}\text { Incidence of postoperative infectious com- } \\
\text { plications lower }\end{array}$ \\
\hline Rayes, 2007 [30] & $\mathrm{RCT}$ & $40 / 40$ & $\begin{array}{l}\text { P. pentosaceus, L. mesenteroides, L. par- } \\
\text { acasei subsp. paracasei, L. plantarum }\end{array}$ & $\begin{array}{l}\text { Incidence of postoperative bacterial infec- } \\
\text { tions significantly lower with Lactobacillt }\end{array}$ \\
\hline Peral, 2009 [31] & $\mathrm{RCT}$ & $38 / 42$ & L. plantarum & $\begin{array}{l}\text { Non-infected 3rd-degree burn: no effect } \\
\text { Infected 2nd-degree burn: suppressed } \\
\text { pathogens, enhanced wound healing } \\
\text { Infected 3rd-degree burn: improved wound } \\
\text { healing }\end{array}$ \\
\hline Peral, 2010 [32] & Pilot study & $34 / 0$ & L. plantarum & $\begin{array}{l}\text { Decreased wound bacterial load and stimu- } \\
\text { lated wound healing }\end{array}$ \\
\hline Liu, 2011 [38] & RCT & $50 / 50$ & L. plantarum, L. acidophilus, B. longum & $\begin{array}{l}\text { Enhanced transepithelial resistance, } \\
\text { reduced blood enteropathogenic bacteria, } \\
\text { fewer surgical site infections }\end{array}$ \\
\hline Usami, 2011 [33] & $\mathrm{RCT}$ & $32 / 29$ & L. casei, B. breve & No infectious complications \\
\hline Zhang, 2012 [34] & $\mathrm{RCT}$ & $30 / 30$ & B. longum, L. acidophilus & $\begin{array}{l}\text { Decreased postoperative occurrence of } \\
\text { infectious complications }\end{array}$ \\
\hline Kotzampassi, 2015 [35] & RCT & $84 / 80$ & $\begin{array}{l}\text { L. acidophilus, L. plantarum, B. lactis, } S \text {. } \\
\text { boulardii }\end{array}$ & $\begin{array}{l}\text { Decrease in incidence of postoperative } \\
\text { pneumonia and of surgical site infections }\end{array}$ \\
\hline El Ghazely, 2016 [36] & $\mathrm{RCT}$ & $20 / 20$ & L. fermentum, L. delbrueckii & $\begin{array}{l}\text { Reduction in incidence of infections, } \\
\text { wound healing enhanced }\end{array}$ \\
\hline Komatsu, 2016 [37] & RCT & $168 / 194$ & L. casei, B. breve & $\begin{array}{l}\text { Synbiotics suppress increase in potentially } \\
\text { pathogenic species, less surgical site } \\
\text { infections (not significant) }\end{array}$ \\
\hline Wälivaara, 2019 [39] & RCT & $32 / 32$ & L. reuteri & $\begin{array}{l}\text { No significant impact of probiotic applica- } \\
\text { tion on wound healing after third molar } \\
\text { extraction }\end{array}$ \\
\hline
\end{tabular}

L., Lactobacillus; S., Saccharomyces; B, Bifidobacterium; P., Pediococcus

Table 4 Characteristics of 6 trials with dairy products on wound healing

\begin{tabular}{|c|c|c|c|c|}
\hline First author, year & Study type & Dairy product & $\begin{array}{l}\text { Sample size } \\
\text { Treatment/control group }\end{array}$ & Findings \\
\hline Rodrigues, 2005 [8] & Animal model study (rats) & Kefir & 5 groups of 5 members & Kefir enhanced wound healing \\
\hline Badr, 2012 [40] & $\begin{array}{l}\text { Animal model study (diabetic } \\
\text { mice) }\end{array}$ & Whey protein & $40 / 20$ & $\begin{array}{l}\text { Whey protein enhanced wound } \\
\text { healing in diabetic mice }\end{array}$ \\
\hline Schutt, 2014 [41] & $\begin{array}{l}\text { Cross-over study (clinical diag- } \\
\text { nosis) }\end{array}$ & Ice cream & $6 / 6$ & $\begin{array}{l}\text { Consumption of dairy products had } \\
\text { no influence on microbiome in } \\
\text { oral cavity }\end{array}$ \\
\hline Rouabhia, 2017 [42] & In vitro study & Yogurt & & $\begin{array}{l}\text { Yogurt enhanced gingival epithelial } \\
\text { cell growth and keratin K5 } \\
\text { production }\end{array}$ \\
\hline Hemmati, 2018 [13] & Animal model study (rabbit) & Low-fat milk ointment & 6 groups of 6 members & $\begin{array}{l}\text { Low-fat milk ointment enhanced } \\
\text { wound healing rate }\end{array}$ \\
\hline Oryan, 2018 [17] & $\begin{array}{l}\text { Animal model study (burn wound } \\
\text { from rats) }\end{array}$ & Kefir & 12 & $\begin{array}{l}\text { Improvement of angiogenesis and } \\
\text { proliferation of fibroblasts }\end{array}$ \\
\hline
\end{tabular}


Table 5 Response rate and study participants by specialization, in Germany and international

\begin{tabular}{lllllll}
\hline Specialization & $\begin{array}{l}\text { Contacted } \\
\text { Germany }\end{array}$ & $\begin{array}{l}\text { Response rate } \\
\text { Germany }\end{array}$ & $\begin{array}{l}\text { Response rate } \\
\text { Germany }\end{array}$ & $\begin{array}{l}\text { Contacted Inter- } \\
\text { national }\end{array}$ & $\begin{array}{l}\text { Response rate } \\
\text { International }\end{array}$ & $\begin{array}{l}\text { Response rate } \\
\text { International }\end{array}$ \\
\hline OMFS & 17 & 13 & $76.5 \%$ & 61 & 45 & $73.8 \%$ \\
Oral surgeon & 30 & 25 & $83.3 \%$ & 6 & 6 & $100.0 \%$ \\
Dentist/periodontist & 103 & 76 & $73.8 \%$ & 76 & 57 & $75.0 \%$ \\
Total & 150 & 114 & $76.0 \%$ & 143 & 108 & $75.5 \%$ \\
\hline
\end{tabular}

Table 6 Guidelines or recommendations regarding milk and dairy products after oral surgery and comments by country

\begin{tabular}{|c|c|c|}
\hline Country & $\begin{array}{l}\text { Guidelines or } \\
\text { recommenda- } \\
\text { tions }\end{array}$ & Comments \\
\hline Argentina & Yes/no & $\begin{array}{l}\text { Avoidance only in the older generation of surgeons because of resorbable suture materials used formerly } \\
\text { such as catgut and because of increasing bacteria level and metabolism }\end{array}$ \\
\hline Austria & Yes & \\
\hline Belgium (Flemish) & Yes & $\begin{array}{l}\text { Whenever patient is unable to clean the mouth properly: avoidance of milk-based products in the first } \\
\text { week to avoid fermentation and bad oral odor }\end{array}$ \\
\hline Belgium (Walloon) & No & $\begin{array}{l}\text { No restrictions. On the contrary: milkshakes with eggs and sugar and cream (calories and proteins) } \\
\text { recommended }\end{array}$ \\
\hline Brazil & No & \\
\hline Chile & No & $\begin{array}{l}\text { The protocols issued by universities and Health Ministry do not avoid milk or dairy. Also, the Universi- } \\
\text { dad Austral in the city of Valdivia (area with greatest German influence) does not make recommenda- } \\
\text { tions to avoid milk or dairy after oral surgery }\end{array}$ \\
\hline China & No & $\begin{array}{l}\text { The older generation recommended to avoid food products which are infested with bacteria rapidly, i.e., } \\
\text { within a few hours or with change in quality difficult to detect. With the wide availability of frozen } \\
\text { food and refrigerators, foods can be stored for a much longer time without degenerating }\end{array}$ \\
\hline Denmark & No & \\
\hline England & No & \\
\hline Estonia & No & \\
\hline France & No & \\
\hline Germany & Yes & \\
\hline India & No & $\begin{array}{l}\text { Consumption of milk and dairy products recommended after all minor oral surgery procedures. A usual } \\
\text { practice is asking the patient to start having ice creams around } 30 \text { min to } 1 \mathrm{~h} \text { post any minor surgical } \\
\text { procedure }\end{array}$ \\
\hline Iran & No & \\
\hline Israel & No & \\
\hline Italy & No & Some surgeons suggest a liquid or soft and creamy diet (yoghurt or milk shakes in particular) \\
\hline Japan & No & \\
\hline Lithuania & No & \\
\hline Malaysia & No & \\
\hline Netherlands & No & \\
\hline Norway & No & \\
\hline Portugal & No & \\
\hline Slovenia & No & \\
\hline Slovakia & No & \\
\hline Sweden & No & \\
\hline Switzerland & Yes & \\
\hline Spain & No & \\
\hline Thailand & No & Patients who cannot chew well after receiving oral surgery are recommended to eat ice cream or yoghurt. \\
\hline Yemen & No & \\
\hline USA & No & \\
\hline
\end{tabular}


Table 7 Recommended behavior after dentoalveolar surgery in relation to milk and dairy products by dentistry specialty in Germany and International

\begin{tabular}{|c|c|c|c|}
\hline Region & Dentistry specialty & $\begin{array}{l}\text { Recommendation to abstain } \\
\text { from milk/dairy products }\end{array}$ & $\begin{array}{l}\text { No recommendation to } \\
\text { abstain from milk/dairy } \\
\text { products }\end{array}$ \\
\hline Germany & $\begin{array}{l}\text { OMFS } \\
(n=13)\end{array}$ & $\begin{array}{l}30.8 \% \\
(n=4)^{* a}\end{array}$ & $\begin{array}{l}69.2 \% \\
(n=9)\end{array}$ \\
\hline Germany & $\begin{array}{l}\text { Oral surgeon } \\
(n=25)\end{array}$ & $\begin{array}{l}48.0 \% \\
(n=12)\end{array}$ & $\begin{array}{l}52.0 \% \\
(n=13)\end{array}$ \\
\hline Germany & $\begin{array}{l}\text { OMFS/oral surgeon } \\
(n=38)\end{array}$ & $\begin{array}{l}42.1 \% \\
(n=16)^{* \mathrm{~b}}\end{array}$ & $\begin{array}{l}57.9 \% \\
(n=22)\end{array}$ \\
\hline Germany & $\begin{array}{l}\text { General dentist } \\
(n=76)\end{array}$ & $\begin{array}{l}64.9 \% \\
(n=49)^{* a, b}\end{array}$ & $\begin{array}{l}35.1 \% \\
(n=27)\end{array}$ \\
\hline Germany & $\begin{array}{l}\text { Total } \\
(n=114)\end{array}$ & $\begin{array}{l}56.1 \% \\
(n=64) * * c\end{array}$ & $\begin{array}{l}43.9 \% \\
(n=50)\end{array}$ \\
\hline International & $\begin{array}{l}\text { Total } \\
(n=108)\end{array}$ & $\begin{array}{l}4.6 \% \\
(n=5)^{* * c}\end{array}$ & $\begin{array}{l}95.4 \% \\
(n=103)\end{array}$ \\
\hline
\end{tabular}

*Correlation is significant at $p<0.05$ level (Fisher's exact test)

**Correlation is significant at $p<0.01$ level (Fisher's exact test)

${ }^{\mathrm{a}}$ Correlation dentists/OMFS ${ }^{\mathrm{b}}$ Correlation oral surgeons and OMFS/dentists ${ }^{\mathrm{c}}$ Correlation total international/total Germany only

Table 8 Source of information stated by dentists, specialist dentists for oral surgery and OMFS regarding consumption of milk and dairy products after dentoalveolar surgery in Germany and international (multiple responses allowed) [6]

\begin{tabular}{|c|c|c|c|c|c|}
\hline Source of Information & $\begin{array}{l}\text { Dentists } \\
\text { (international }+ \\
\text { Germany) } \\
(n=133)\end{array}$ & $\begin{array}{l}\text { Specialist dentists for oral } \\
\text { surgery (international + } \\
\text { Germany) } \\
(n=31)\end{array}$ & $\begin{array}{l}\text { OMFS (inter- } \\
\text { national + } \\
\text { Germany) } \\
(n=58)\end{array}$ & $\begin{array}{l}\text { Total (inter- } \\
\text { national }+ \\
\text { Germany) } \\
(n=222)\end{array}$ & $\begin{array}{l}\text { Total } \\
\text { (Germany } \\
\text { only) } \\
(n=114)\end{array}$ \\
\hline Teaching at University & $\begin{array}{l}29.3 \% \\
(n=39) \\
* * * a\end{array}$ & $\begin{array}{l}41.9 \% \\
(n=13) \\
* * * \mathrm{~b}\end{array}$ & $\begin{array}{l}0 \% \\
(n=0) \\
* * * \mathrm{~b}\end{array}$ & $\begin{array}{l}23.4 \% \\
(n=52) \\
* * * c\end{array}$ & $\begin{array}{l}45.6 \% \\
(n=52) \\
* * * c\end{array}$ \\
\hline $\begin{array}{l}\text { Recommendations by other dentists } \\
\text { - Lactobacilli could affect wound healing }\end{array}$ & $\begin{array}{l}12.8 \% \\
(n=17) \\
* \mathrm{a}\end{array}$ & $\begin{array}{l}22.6 \% \\
(n=7) \\
* * \mathrm{~b} \\
* \mathrm{a}\end{array}$ & $\begin{array}{l}1.7 \% \\
(n=1) \\
* * \mathrm{~b}\end{array}$ & $\begin{array}{l}11.3 \% * \\
(n=25) \\
* \mathrm{c}\end{array}$ & $\begin{array}{l}21.1 \% * \\
(n=24) \\
* \mathrm{c}\end{array}$ \\
\hline $\begin{array}{l}\text { Personal experience } \\
\text { - To avoid fermentation and bad oral } \\
\text { odor } \\
\text { - Dairy products could increase the } \\
\text { bacteria level and metabolism } \\
\text { - (old) resorbable suture materials could } \\
\text { resorb faster }\end{array}$ & $\begin{array}{l}12.0 \% \\
(n=16)\end{array}$ & $\begin{array}{l}38.7 \% \\
(n=12) \\
* * \mathrm{~b}\end{array}$ & $\begin{array}{l}8.6 \% \\
(n=5) \\
* * b\end{array}$ & $\begin{array}{l}14.9 \% \\
(n=33)\end{array}$ & $\begin{array}{l}25.4 \% \\
(n=29)\end{array}$ \\
\hline Specialist literature & $\begin{array}{l}6.8 \% \\
(n=9) \\
* * \mathrm{~d}\end{array}$ & $\begin{array}{l}25.8 \% \\
(n=8) \\
* * * \mathrm{~b} \\
* * \mathrm{~d}\end{array}$ & $\begin{array}{l}0=\% \\
(n=0) \\
* * * b\end{array}$ & $\begin{array}{l}7.7 \% \\
(n=17) \\
* * \mathrm{c}\end{array}$ & $\begin{array}{l}18.4 \% \\
(n=21) \\
* * \mathrm{c}\end{array}$ \\
\hline Not specified & $\begin{array}{l}42.9 \% \\
(n=57)\end{array}$ & $\begin{array}{l}19.4 \% \\
(n=6)\end{array}$ & $\begin{array}{l}70.7 \% \\
(n=41)\end{array}$ & $\begin{array}{l}46.8 \% \\
(n=104)\end{array}$ & $\begin{array}{l}0 \% \\
(n=0)\end{array}$ \\
\hline
\end{tabular}

*Correlation is significant at $p<0.05$ level (Fisher's exact test)

**Correlation is significant at $p<0.01$ level (Fisher's exact test)

$* * *$ Correlation is significant at $p<0.001$ level (Fisher's exact test)

healing to milk and dairy products [6]. Compared to the international collective, there was a striking difference regarding the sources of information given by OMFS and specialist dentists for oral surgery (Table 8 ). Oral surgeons stated lectures at university, specialist literature, personal experience, and recommendations from other dentists as sources of information significantly more frequently. We have been unable, however, to identify the exact specific original source of the recommendation to abstain from dairy products as traditionally made at many German 
universities. At the time of the First World War, the recommended diet [43] for patients who had sustained injuries to the jaw was liquids, specifically soup, milk in any form, dishes with eggs, and a variety of meat extracts [43]. Textbooks from the time of the Second World War still recommended a diet containing eggs, milk, and cocoa for same patients [44]. Therefore, the current recommendation was only propagated after the World War II.

Regarding the reasons given as listed in Table 1, the theory of an interaction between milk and antibiotics may apply for some classes of agents, e.g., tetracycline and quinolone (neither an antibiotic of preferred choice in dentistry). Milk and dairy products may indeed reduce bioavailability of tetracyclines by up to $80 \%$ [45]. The most frequently used antibiotics in dentistry, however, such as amoxicillin, propicillin, phenoxlmethyl penicillin, and clindamycin, and less frequently used cefaclor, cefuroxime, cefpodoxime, erythromycin, roxithromycin, clarithromycin, azithromycin, nitroimidazole, and metronidazole [46], do not interact with milk and dairy products. It is well known that milk is a good culture medium for certain bacterial colonies. As it is rich in numerous amino acids and minerals and due to the lactose contained inside, it may promote growth of bacteria, including pathogenic bacteria in the oral cavity, with adverse effect on wounds. And while lactobacilli are indeed required for the production of dairy products, such as yoghurt and cheese, exclusively such thermophile lactic acid bacteria are utilized here which are not pathogenic.

It is further argued that clotting may be inhibited by consumption of dairy products, with a risk of resulting dry socket and dolor post extractionem. Fibrinolytic plasminogen, which is also been found in milk, is believed to be responsible for the inhibition of clotting. The determining factor for the evaluation of the effect of plasminogen on coagulum development is concentration in milk $(0.3-2.5 \mu \mathrm{g} /$ $\mathrm{ml})$ compared to serum concentration $(200 \mu \mathrm{g} / \mathrm{ml})$ [47]. The plasmin concentration in blood is $100-1000$ times higher than in milk. The conclusion may be that the effect of milk on blood coagulation is not relevant and negligible in comparison to the concentration of plasminogen in the coagulum itself.

Some practitioners argue that milk and dairy products will react with resorbable sutures. In many resorbable suture materials, the degradation process is of a hydrolytic nature. In order for, e.g., tensile strength of suture material to be affected by dairy products, $\mathrm{pH}$ would need to be affected for an extended period of time. Absorbable suture materials are relatively more sensitive to the $\mathrm{pH}$ value than non-resorbable materials. The degradation of synthetic resorbable sutures, however, is more pronounced in an alkaline milieu in general rather than at physiological or acidic $\mathrm{pH}$ range [48]. Some opponents believe in a historical basis of the recommendation to avoid dairy products after oral surgery in an empirically elevated risk of contracting tuberculosis after consumption of dairy products in the past-obsolete today. Tuberculosis is a bacterial infectious disease, caused by the obligate pathogenic Mycobacterium tuberculosis complex, M. tuberculosis, M. bovis, and M. caprae. The latter two are zoonoses, communicable from infected animals to humans. A tuberculosis infection in humans most frequently develops into pulmonary tuberculosis and is currently the most widespread lethal bacterial infectious disease, with 10 Million individuals developing tuberculosis annually. According to the World Health Organization (WHO), there were about 1.4 million deaths due to tuberculosis worldwide in 2019, with Bangladesh, China, India, Indonesia, Nigeria, Pakistan, the Philippines, and South Africa accounting for approx. half of all known cases of tuberculosis [49]. A variety of tuberculosis is $M$. bovis which is transmitted through consumption of unpasteurized milk. Those affected by cervical tuberculous lymphadenitis, also called scrofula (historically known as The King's Evil) [50], will exhibit cervical gland tumors and abscesses and lesions of the skin in the area of the affected lymph nodes. According to the WHO, extrapulmonary tuberculosis was diagnosed in $15 \%$ of the 6.3 million cases in Europe in 2016. The majority of cases of tuberculous cervical lymphadenopathy, however, occur in developing countries. In Europe, infections with Mycobacteria mainly affect immigrants and immunocompromised individuals. Women are relatively more frequently affected by scrofulosis, men by pulmonary tuberculosis [51]. The disease may recur and develop into a chronic, progressive form, Lupus vulgaris (Tuberculosis luposa or ulcerative Lupus faciei). The belief that raw milk may incur the risk of infection with tuberculosis was still well founded at the beginning of the twentieth century; in 1901, as many as $80 \%$ of cattle in Germany tested positive for tuberculin [52]. However, since 1997, the cattle population in Germany has been officially declared free from tuberculosis, as $99.9 \%$ of cattle are not affected [53]. Currently, the majority of cases of bovine tuberculosis occur in countries such as Ethiopia, India, and China, which also frequently report cases of tuberculosis in humans [53-57]. Why no recommendation is made in these countries to abstain from consumption of dairy products after dentoalveolar surgery yet needs to be established. In Germany, tuberculosis is a notifiable disease and affected cattle populations are required by law to be culled. Milk undergoes heat treatment (pasteurization/ultra-high temperature treatment), destroying all pathogenic germs, including Mycobacteria in the milk, and a danger of infection through consumption of milk after dentoalveolar surgery no longer exists $[47,58]$. According to the Centers for Disease Control and Prevention (CDC), the risk of infection through contaminated raw milk is 150 times greater than by consuming pasteurized milk. Especially infants, pregnant women and people with weakened immune systems are in danger of illnesses and 
hospitalization. These pathogens are most often Brucella, Campylobacter, Cryptosporidium, E. coli, Listeria, Salmonella, and mastitic streptococci [59].

Some dentists advise against dairy products because of contained bacterial cultures. Live probiotic cultures are part of fermented dairy products and are intended to have health benefits when consumed. Those microorganisms also occur naturally in lactic acid products such as yogurt, kefir, or buttermilk. That is why we have made a literature review on probiotics to find out if there are any possible wound healing disorders or wound infections after use of probiotics. Our review also encompasses studies into the effect of probiotics and synbiotics on a variety of skin wounds including infected and non-infected wounds, diabetic wounds, and burn injury models. The studies, in vitro and in vivo, all arrived at the identical result and conclusion that probiotics and synbiotics are able to inhibit those wound pathogens which cause surgical site infections [60] and thus will sometimes be able to reduce required hospitalization and quantity of antibiotics [27, 29, 30, 34]. This may also help prevent development of multidrug resistant bacteria. Moreover, the use of probiotics helped to reduce inflammatory markers [ 15 , $22,61]$. These results of our literature search agreed with the results of other systematic reviews into the influence of probiotics, prebiotics, and/or synbiotics [42, 62-64]. As our research question focuses on the effect of dairy products in the oral cavity, the caveat would be that the available literature mainly deals with the effect of probiotics on skin wounds. In an additional in vitro study into the post-wound interactions between gingival epithelial cells and drinkable yogurt, the authors observed a positive effect on oral wound healing. This was explained by an increase in various keratins and in $\beta$-defensin- 2 production [65]. These keratins are important for the development of epidermal structures [66]. $\beta$-defensin stimulates cell migration and angiogenesis at wound sites and promotes wound closure $[38,65]$.

There are several limitations to this study. While the German survey may well be considered representative, the international survey so far constitutes a mere random sample of individuals. Even though they are generally based at universities, the results are not representative or robust for worldwide validity. They may, however, well constitute evidence of a trend. Further national surveys may be able to offer evidence-based validity.

As our research question investigates the effect of dairy products in the oral cavity, our review of probiotics was included with the reservation that it mainly covers skin wounds. The majority of the in vivo studies reviewed were conducted in countries in Asia and Europe. They may therefore not generally applicable for other populations.

\section{Conclusion}

Available data indicate that the German-speaking areas differ significantly in their dietary recommendations after dentoalveolar surgery. The recommendation to abstain from milk and dairy products, as made by over $50 \%$ of dentists surveyed in the German pilot study, is neither evidencebased nor can its origin or scientific basis be established. Most plausible seems the empirical experience with historical background (scrofula), which today can safely be considered as no longer relevant due to pasteurization of milk. Taking on board the fact that the incidence of tuberculosis is on the rise again, and so are antibiotic-resistant strains, a possible transoral access of tuberculosis should not be taken lightly or disregarded.

The validity of the routine recommendation to abstain from consumption of milk and dairy products after dentoalveolar surgery, a widespread practice in Germany today, nevertheless should be challenged and re-examined.

Availability of data and materials Not applicable

Code availability Not applicable

Funding Open Access funding enabled and organized by Projekt DEAL.

\section{Declarations}

Ethics approval The underlying study for this contribution was approved by the ethics commission of the Philipps-Universität Marburg, Germany (Study 118/19).

Conflict of interest The authors declare no conflict of interest.

Open Access This article is licensed under a Creative Commons Attribution 4.0 International License, which permits use, sharing, adaptation, distribution and reproduction in any medium or format, as long as you give appropriate credit to the original author(s) and the source, provide a link to the Creative Commons licence, and indicate if changes were made. The images or other third party material in this article are included in the article's Creative Commons licence, unless indicated otherwise in a credit line to the material. If material is not included in the article's Creative Commons licence and your intended use is not permitted by statutory regulation or exceeds the permitted use, you will need to obtain permission directly from the copyright holder. To view a copy of this licence, visit http://creativecommons.org/licenses/by/4.0/.

\section{References}

1. James SL, Abate D, Abate KH et al (2018) Global, regional, and national incidence, prevalence, and years lived with disability for 354 diseases and injuries for 195 countries and territories, 1990-2017: a systematic analysis for the Global Burden of Disease Study 2017. The Lancet 392:1789-1858. https://doi.org/10. 1016/S0140-6736(18)32279-7 
2. Buch R, Walter C, Moralis A et al. (2005) Dolor post extractionem: Die lokale Therapie der Alveolitis mit medikamentösen Einlagen. zm

3. Techniker Krankenkasse (2020) Nach der Zahnentfernung. https:// www.tk.de/techniker/gesundheit-und-medizin/behandlungen-undmedizin/zaehne-und-kieferorthopaedie/nach-der-zahnentfernung2021592. Accessed 15 May 2021

4. Google search (2021) milch implantat. https://www.google. $\mathrm{de} /$ search $? \mathrm{q}=$ milch + implantat\&sxsrf $=\mathrm{ALeKk} 01 \mathrm{tF} \_$VCKCW qzgINVtq0Ov_1OqdtVg\%3A1620899058113\&source=hp\&ei= 8vScYOOlAoOHjLsPiM2k6AQ\&iflsig=AINFCbYAAAAAYJ0 DAi_VWHQk66kHjRBEZaMWVBxIgNZx\&oq=milch+impla ntat\&gs_lcp $=$ Cgdnd3Mtd216EAMyBAgjECcyBAgjECcyBgg AEBYQHjIGCAAQFhAeMgYIABAWEB4yBggAEBYQHjo HCCMQ6gIQJzoFCAAQsQM6AggAOgsIABCxAxDHARC jAjoICAAQsQMQgwE6BAgAEEM6BQguELEDOggILhC xAxCDAToHCAAQsQMQQzoHCC4QsQMQQ1DrCliYHWC $\mathrm{uJ} 2 \mathrm{gBcAB} 4 \mathrm{AIABX} 4 \mathrm{gB} 8 \mathrm{giSAQIxNZgBAKABAaoBB} 2 \mathrm{~d} 3 \mathrm{cy} 13$ aXqwAQo\&sclient $=$ gws-wiz\&ved=0ahUKEwjj5sjEr8bwAhW DA2MBHYgmCU0Q4dUDCAk\&uact=5. Accessed 02 Feb 2021

5. Google search (2021) milchprodukte zahn. https://www.google. $\mathrm{de} /$ search? $\mathrm{q}=$ milchprodukte+zahn\&sxsrf=ALeKk02Ylpt2QJm DtZF81ODxo18uih0nvQ\%3A1620899063894\&ei=9_ScYLT wNcmH9u8Phduk2AE\&oq=milchprodukte+zahn\&gs_lcp= Cgdnd3Mtd216EAMyBAgjECcyAggAMgIIADICCAAyAggAM gIIADICCAAyBggAEBYQHjIGCAAQFhAeMgYIABAWE B46BwgjELADECc6BwgAEEcQsA M6Bgg AEAcQHjoIC AAQCBAHEB46CAgAEAcQBRAeOgYIABAIEB5Q_ZgHWK bLB2DQ0AdoAXACeACAAZwEiAH9JZIBDDAuMTMuNC 4zLjEuMZgBAKABAaoBB2d3cy13aXrIAQrAAQE\&sclient= gws-wiz\&ved=0ahUKEwj0x63Hr8bwAhXJg_0HHYUtCRsQ 4dUDCA0\&uact $=5$. Accessed 02 Feb 2021

6. Seyedi Moghaddam S, Neff A (2020) Wie halten Sie es mit Milchprodukten nach dentoalveolär-chirurgischen Eingriffen: Erlaubt oder nicht? MKG-Chirurg 13:55-60. https://doi.org/10.1007/ s12285-019-00238-1

7. Valdez JC, Peral MC, Rachid M et al (2005) Interference of Lactobacillus plantarum with Pseudomonas aeruginosa in vitro and in infected burns: the potential use of probiotics in wound treatment. Clinical microbiology and infection 11:472-479

8. Rodrigues KL, Caputo LRG, Carvalho JCT et al (2005) Antimicrobial and healing activity of kefir and kefiran extract. International Journal of Antimicrobial Agents 25:404-408. https://doi. org/10.1016/j.ijantimicag.2004.09.020

9. Brachkova MI, Marques P, Rocha J et al (2011) Alginate films containing Lactobacillus plantarum as wound dressing for prevention of burn infection. Journal of Hospital Infection 79:375-377

10. Nasrabadi H, Ebrahimi T (2011) Comparison of the effects of Lactobacillus brevis and Lactobacillus plantarum on cutaneous wound healing in rats. African Journal of Microbiology Research 5:4226-4233

11. Jones M, Ganopolsky JG, Labbé A et al (2012) Novel nitric oxide producing probiotic wound healing patch: preparation and in vivo analysis in a New Zealand white rabbit model of ischaemic and infected wounds. Int Wound J 9:330-343. https://doi.org/10. 1111/j.1742-481X.2011.00889.x

12. Poutahidis T, Kearney SM, Levkovich T et al (2013) Microbial symbionts accelerate wound healing via the neuropeptide hormone oxytocin. PLoS One 8:e78898. https://doi.org/10.1371/ journal.pone.0078898

13. Hemmati AA, Larki-Harchegani A, Shabib S et al (2018) Wound healing property of milk in full thickness wound model of rabbit. Int J Surg 54:133-140. https://doi.org/10.1016/j.ijsu.2018.04.030

14. Partlow J, Blikslager A, Matthews C et al (2016) Effect of topically applied Saccharomyces boulardii on the healing of acute porcine wounds: a preliminary study. BMC Res Notes 9:210. https://doi.org/10.1186/s13104-016-2012-8

15. Argenta A, Satish L, Gallo P et al (2016) Local application of probiotic bacteria prophylaxes against sepsis and death resulting from burn wound infection. PLoS One 11:e0165294. https://doi. org/10.1371/journal.pone.0165294

16. Satish L, Gallo PH, Johnson S et al (2017) Local probiotic therapy with Lactobacillus plantarum Mitigates scar formation in rabbits after burn injury and infection. Surg Infect (Larchmt) 18:119-127. https://doi.org/10.1089/sur.2016.090

17. Oryan A (2018) Kefir accelerates burn wound healing through inducing fibroblast cell migration in vitro and modulating the expression of IL-1ss, TGF-ss1, and bFGF genes in vivo. Probiotics Antimicrob Proteins: 874

18. Ong JS, Taylor TD, Yong CC et al (2019) Lactobacillus plantarum USM8613 aids in wound healing and suppresses Staphylococcus aureus infection at wound sites. Probiotics and antimicrobial proteins: $1-13$

19. Tagliari E, Campos LF, Campos AC et al (2019) Effect of probiotic oral administration on skin wound in rats. Arq Bras Cir Dig 32:e1457. https://doi.org/10.1590/0102-672020190001e1457

20. Khodaii Z, Afrasiabi S, Hashemi SA et al. (2019) Accelerated wound healing process in rat by probiotic Lactobacillus reuteri derived ointment. J Basic Clin Physiol Pharmacol 30. https://doi. org/10.1515/jbcpp-2018-0150

21. Han N, Jia L, Su Y et al (2019) Lactobacillus reuteri extracts promoted wound healing via PI3K/AKT/ $\beta$-catenin/TGF $\beta 1$ pathway. Stem cell research \& therapy 10:243. https://doi.org/10.1186/ s13287-019-1324-8

22. Oryan A, Alemzadeh E, Eskandari MH (2019) Kefir accelerates burn wound healing through inducing fibroblast cell migration in vitro and modulating the expression of IL-1B, TGF- 31 , and bFGF genes in vivo. Probiotics and antimicrobial proteins 11:874886. https://doi.org/10.1007/s12602-018-9435-6

23. Mohtashami M, Mohamadi M, Azimi-Nezhad M et al (2020) Lactobacillus bulgaricus and Lactobacillus plantarum improve diabetic wound healing through modulating inflammatory factors. Biotechnol Appl Biochem. https://doi.org/10.1002/bab.2064

24. Ong JS, Taylor TD, Yong CC et al (2020) Lactobacillus plantarum USM8613 aids in wound healing and suppresses Staphylococcus aureus infection at wound sites. Probiotics and antimicrobial proteins 12:125-137. https://doi.org/10.1007/s12602-018-9505-9

25. Moreira CF, Cassini-Vieira P, Canesso MCC et al. (2021) Lactobacillus rhamnosus CGMCC 1.3724 (LPR) improves skin wound healing and reduces scar formation in mice. Probiotics and antimicrobial proteins. https://doi.org/10.5897/AJB10.1999

26. Han N, Jia L, Guo L et al (2020) Balanced oral pathogenic bacteria and probiotics promoted wound healing via maintaining mesenchymal stem cell homeostasis. Stem cell research \& therapy 11:61. https://doi.org/10.1186/s13287-020-1569-2

27. Rayes N, Hansen S, Seehofer D et al (2002) Early enteral supply of fiber and Lactobacilli versus conventional nutrition: a controlled trial in patients with major abdominal surgery. Nutrition 18:609-615

28. Kanazawa H, Nagino M, Kamiya S et al (2005) Synbiotics reduce postoperative infectious complications: a randomized controlled trial in biliary cancer patients undergoing hepatectomy. Langenbeck's archives of surgery 390:104-113

29. Sugawara G, Nagino M, Nishio H et al (2006) Perioperative synbiotic treatment to prevent postoperative infectious complications in biliary cancer surgery: a randomized controlled trial. Ann Surg 244:706

30. Rayes N, Seehofer D, Theruvath T et al (2007) Effect of enteral nutrition and synbiotics on bacterial infection rates after pyloruspreserving pancreatoduodenectomy: a randomized, double-blind trial. Ann Surg 246:36 
31. Peral MC, Martinez MAH, Valdez JC (2009) Bacteriotherapy with Lactobacillus plantarum in burns. Int Wound J 6:73-81. https:// doi.org/10.1111/j.1742-481X.2008.00577.x

32. Peral MC, Rachid MM, Gobbato NM et al (2010) Interleukin-8 production by polymorphonuclear leukocytes from patients with chronic infected leg ulcers treated with Lactobacillus plantarum. Clin Microbiol Infect 16:281-286. https://doi.org/10.1111/j.14690691.2009.02793.x

33. Usami M, Miyoshi M, Kanbara Y et al (2011) Effects of perioperative synbiotic treatment on infectious complications, intestinal integrity, and fecal flora and organic acids in hepatic surgery with or without cirrhosis. Journal of Parenteral and Enteral Nutrition 35:317-328

34. Zhang J-W, Du P, Yang B-R et al (2012) Preoperative probiotics decrease postoperative infectious complications of colorectal cancer. The American journal of the medical sciences 343:199-205

35. Kotzampassi K, Stavrou G, Damoraki G et al (2015) A four-probiotics regimen reduces postoperative complications after colorectal surgery: a randomized, double-blind, placebo-controlled study. World journal of surgery 39:2776-2783

36. El-Ghazely MH, Mahmoud WH, Atia MA et al (2016) Effect of probiotic administration in the therapy of pediatric thermal burn. Annals of burns and fire disasters 29:268

37. Komatsu S, Sakamoto E, Norimizu S et al (2016) Efficacy of perioperative synbiotics treatment for the prevention of surgical site infection after laparoscopic colorectal surgery: a randomized controlled trial. Surgery today 46:479-490

38. Hirsch T, Spielmann M, Zuhaili B et al (2009) Human beta-defensin-3 promotes wound healing in infected diabetic wounds. J Gene Med 11:220-228. https://doi.org/10.1002/jgm.1287

39. Wälivaara D-Å, Sjögren I, Gerasimcik N et al (2019) Effects of Lactobacillus reuteri-containing lozenges on healing after surgical removal of mandibular third molars: a randomised controlled trial. Beneficial Microbes 10:653-659. https://doi.org/10.3920/ BM2018.0168

40. Badr G (2012) Supplementation with undenatured whey protein during diabetes mellitus improves the healing and closure of diabetic wounds through the rescue of functional long-lived wound Macrophages. Cell Physiol Biochem 29:571-582. https://doi.org/ 10.1159/000338511

41. Schutt CA, Neubauer P, Paskhover B et al (2014) The impact of dairy consumption on salivary inoculum. Dysphagia 29:277-282. https://doi.org/10.1007/s00455-013-9508-3

42. Fijan S, Frauwallner A, Langerholc T et al (2019) Efficacy of using probiotics with antagonistic activity against pathogens of wound infections: an integrative review of literature. Biomed Res Int 2019:7585486. https://doi.org/10.1155/2019/7585486

43. Feiler E (1916) Der Zahnarzt im Felde:(aus der Kiefer-und Zahnstation eines aktiven Armee-Korps im Felde). Meusser

44. Reichenbach E (1940) Erste kieferchirurgische Erfahrungen aus dem Feldzug gegen Polen. Lehmanns

45. Gerdemann A, Griese N, Schulz M (2008) Interaktionen: Tetracycline und polyvalente Kationen. https://www.pharmazeutischezeitung.de/ausgabe-112008/tetracycline-und-polyvalente-katio nen/. Accessed 02 Jul 2019

46. Halling F (2014) Antibiotika in der Zahnmedizin. Zahnmedizin up2date 8:67-82. https://doi.org/10.1055/s-0033-1346918

47. Belitz H-D, Grosch W, Schieberle P (2008) Lehrbuch der Lebensmittelchemie, 6th edn. Springer, Berlin, Heidelberg

48. Chu CC, Moncrief G (1983) An in vitro evaluation of the stability of mechanical properties of surgical suture materials in various pH conditions. Ann Surg 198:223-228. https://doi.org/10.1097/ 00000658-198308000-00019

49. Baddeley A, Bartens M-C, Dean A et al. (2020) Global tuberculosis report 2020. https://apps.who.int/iris/bitstream/handle/10665/ 336069/9789240013131-eng.pdf. Accessed 15 May 2021
50. Bloom H, Marson J (eds) (op. 2008) Macbeth. Bloom's Shakespeare through the ages. Checkmark Books, New York

51. Fontanilla J-M, Barnes A, von Reyn CF (2011) Current diagnosis and management of peripheral tuberculous lymphadenitis. Clin Infect Dis 53:555-562. https://doi.org/10.1093/cid/cir454

52. Buchwald G. (2002) Der Rückgang der Schwindsucht trotz "Schutzimpfung". F. Hirthammer Verlag, München

53. Eisenberg T, Menge C (2017) Epidemiologisches Bulletin: Zoonotische Infektionen mit Mycobacterium tuberculosis in deutschen Nutztierbeständen. 10.17886/EPIBULL-2017-027

54. Berg S, Firdessa R, Habtamu M et al (2009) The burden of mycobacterial disease in Ethiopian cattle: implications for public health. PLoS One 4:e5068. https://doi.org/10.1371/journal.pone. 0005068

55. Chen Y, Chao Y, Deng Q et al (2009) Potential challenges to the Stop TB Plan for humans in China; cattle maintain M. bovis and M. tuberculosis. Tuberculosis (Edinb) 89:95-100. https://doi.org/ 10.1016/j.tube.2008.07.003

56. Fetene T, Kebede N, Alem G (2011) Tuberculosis infection in animal and human populations in three districts of Western Gojam, Ethiopia. Zoonoses Public Health 58:47-53. https://doi.org/10. 1111/j.1863-2378.2009.01265.x

57. Singh SK, Verma R, Shah DH (2004) Molecular fingerprinting of clinical isolates of Mycobacterium bovis and Mycobacterium tuberculosis from India by restriction fragment length polymorphism (RFLP). J Vet Sci 5:331-335

58. Strahm W, Eberhard P (2009) Trinkmilchtechnologien - Eine Übersicht. www.agroscope.admin.ch. Accessed 24 Jun 2019

59. Rea MC, Cogan TM, Tobin S (1992) Incidence of pathogenic bacteria in raw milk in Ireland. J Appl Bacteriol 73:331-336. https://doi.org/10.1111/j.1365-2672.1992.tb04985.x

60. Malic S, Hill KE, Playle R et al (2011) In vitro interaction of chronic wound bacteria in biofilms. Journal of Wound Care 20:569-70, 572, 574-7. https://doi.org/10.12968/jowc.2011.20. 12.569

61. Rayes N, Seehofer D, Neuhaus P (2009) Prebiotics, probiotics, synbiotics in surgery - are they only trendy, truly effective or even dangerous? Langenbeck's archives of surgery 394:547-555

62. Knackstedt R, Knackstedt T, Gatherwright J (2020) The role of topical probiotics on wound healing: a review of animal and human studies. Int Wound J 17:1687-1694. https://doi.org/10. 1111/iwj.13451

63. Kasatpibal N, Whitney JD, Saokaew S et al (2017) Effectiveness of probiotic, prebiotic, and synbiotic therapies in reducing postoperative complications: a systematic review and network metaanalysis. Clinical infectious diseases 64:S153-S160

64. Wu X-D, Liu M-M, Liang X et al (2018) Effects of perioperative supplementation with pro-/synbiotics on clinical outcomes in surgical patients: a meta-analysis with trial sequential analysis of randomized controlled trials. Clinical Nutrition 37:505-515

65. Rouabhia M, Rouabhia D, Park HJ et al (2017) Effect of soft foods on primary human gingival epithelial cell growth and the wound healing process, vol:100

66. Wagner M, Hintner H, Bauer JW et al (2012) Gene expression analysis of an epidermolysis bullosa simplex Dowling-Meara cell line by subtractive hybridization: recapitulation of cellular differentiation, migration and wound healing. Experimental Dermatology 21:111-117. https://doi.org/10.1111/j.1600-0625.2011. 01420.x

Publisher's note Springer Nature remains neutral with regard to jurisdictional claims in published maps and institutional affiliations. 